\section{Korkach H., Krusir G.}

\title{
DEVELOPMENT OF INNOVATIVE TECHNOLOGIES OF FONDANT CANDIES WITH SYNBIOTICS
}

Вивчено роль процесу мікрокапсулювання мікроорганізмів з метою їх захисту від несприятливих факторів. Доведено дочільність створення синбіотичного комплексу і вивчено його вплив на фізико-хімічні і структурно-механічні властивості помадних мас. Надані результати по розробці технології помадних иукерок з синбіотичним комплексом, в якому в якості пробіотичних культур використовували мікрокапсульовані біфідобактерії, а в якості пребіотика - лактулозу.

Ключові слова: мікрокапсульовані біфідобактерї, пребіотик лактулоза, синбіотики, мікрокапсулювання, помадні иукерки.

\section{Introduction}

In the highly competitive market for the sales of confectionery products an urgent task for manufacturers is to develop and implement of innovative technologies at confectionary factories. Today it is impossible to imagine an enterprise without the introduction of new technologies and related equipment that ensures the competitiveness of its products. Despite the significant amount of scientific research to expand the range of products, some aspects of this topic require further research.

Today confectionery industry solves a number of important tasks to improve consumer properties, improve the biological value of the products, to reduce its energy value and sugar content, creation of highly innovative technologies, improvement of the product assortment. These problems can be solved through the development of new formulations of confectionery products with functional food ingredients.

Confectionery industry of Ukraine has very limited assortment of manufactured functional confectionery. Confectionery generally do not meet the norms of a healthy and balanced diet, their quality is not always consistent with consumer demands [1]. Therefore, the task of developing new types of finished functional products is relevant for the scientists and specialists of food industry.

\section{The object of research and its technological audit}

The object of this research is the process of formulating the fondant candies using synbiotic complex.

Fondant candies among a group of sugar confectionery products are in great demand among Ukrainian consumers [1]. Their assortment is varied and can satisfy different tastes. Candies on the basis of sugar fondant consist mainly of carbohydrates. These kinds of confectionery products have a high energy value and do not have the formula of balanced nutrition. In other words, they are the sources of «empty calories». But they may become functionally oriented products if the useful ingredients will add to the formulation.

Microencapsulated bifidobacteria and lactulose are used as the functional ingredients to create synbiotic complex using.
Technological audit is made to define such basic tasks: - Rationale for the choice of pro- and prebiotics to develop synbiotic complex.

- Research of introduction stages for additives in the production of fondant candies.

- Assortment expansion of functional fondant candies.

One of the most challenging technological problems is to maintain the viability of microbial cells during manufacture of products.

\section{The aim and objectives of research}

The aim of research is the scientific rationale and development of technologies of new competitive (in the group of sugar confectionery) fondant candies using synbiotic complex and research of their quality.

In accordance with the aim of research there are the following tasks:

1. Substantiate the method of bifidobacteria microencapsulation as a way to improve their stability.

2. Develop a synbiotic complex for addition into formulation of fondant candies.

3. Investigate the effect of synbiotic additives on the structural-mechanical and physical-chemical properties of fondant candies.

\section{Research of existing solutions of the problem}

Strategic development path of confectionery industry is related to the release of functional foods. These products, besides nutritional value, also have a positive effect on human health (improve the activity of the gastrointestinal tract, enhance immunity, etc.).

According to recent data [2], spread of various forms of dysbiosis is revealed in Ukraine. It is affecting about $80 \%$ of the population. Prevention and treatment of dysbiosis is associated with the restoration of normal intestinal microflora by a pharmacopoeial drugs; dietary supplements; functional food products containing probiotics, prebiotics and synbiotics (Fig. 1).

One of the most important groups of the human synbiotic microflora is Bifidobacterium genus. Representatives 
of this genus are natural inhabitants of the large intestine of children and adults and many species has a considerable number of positive effects on the host organism [3]. Bifidobacteria are constantly present in the gastrointestinal tract and mucosae of the person participate in the morphogenesis and functions of the various systems of the host organism - digestive, immune, cardiovascular, endocrine, etc. This is due to the participation of bifidobacteria in the metabolism of proteins, lipids, carbohydrates, as well as due to the large number of produced biologically active substances: enzymes, proteins, polysaccharides [4-6]. Antagonistic activity of bifidobacteria is associated with production of organic acids, bacteriocins and blocking adhesion sites on the intestinal mucosa. The latter prevents fixation of potentially pathogenic microorganisms on them and causes a critical role of bifidobacteria in colonization resistance $[3,4,6]$.

Due to the products of antagonistic activity against pathogenic and putrefactive microflora, bifidobacteria have a considerable interest as a protective agent of the food [5-7]. Antagonistic activity of bifidobacteria strains is especially important against Staph. aureus, E. coli, Salmonella, Bacilliuscereus, Pseudomonas, Yersinia, Listeria, because these microorganisms in small amounts in foods is a major threat to food safety, and the human health [3, 5].

Stimulants or promoters of probiotics are prebiotics.

Prebiotics have the following requirements. They have to:

- Hydrolyzed or absorbed in the upper part of the intestine.

- Be selective substrate of one or a limited number of useful representatives of normal intestinal microflora, stimulating their growth and/or metabolic activity.

- Be able to improve the composition of intestinal microflora.

- Be safe for the macroorganism [8].

Prebiotic is physiologically functional food ingredient in the form of substance or complex of substances, providing optimization of microecological state of the human body at regular eating in a food composition. This is due to selective stimulation of growth and/or biological activity of normal microflora of the digestive tract. As a result, there is improvement of human health [9]. One of the most famous bifidobacteria growth factors is lactulose. Its prebiotic properties are well understood, it has become a classic means of influence on the metabolism of the intestinal microflora. According to studies [10], to maintain normal intestinal microflora it is recommended to consume $3-5 \mathrm{~g}$ of lactulose per day. It has a number of very valuable properties:

- Activates the vital activity of bifidobacteria and inhibits harmful bacteria.

- Lactulose significantly reduced content of toxic metabolites (ammonia, skatole, indole) and harmful enzymes.

- Use of lactulose promotes calcium absorption, so this is a method of preventing osteoporosis [11].

- Lactulose, when entering the body, reaches the colon, which is cleaved by enzymes of bifidobacteria and lactobacilli to the organic acid: lactic, acetic, butyric, etc. that lower the $\mathrm{pH}$ of the intestine, which inhibits the development of putrefactive microflora, stimulates intestinal peristalsis.

- Has an anticancer action associated with activation of the immune system by bifidobacteria cells, components of cell walls and intracellular components.

- It is an effective way to improve cholesterol metabolism.

Effectiveness of prebiotics and probiotics is greatly enhanced in the case of their co-addition into food products [12].

Functional food ingredients are a combination of probiotics and prebiotics, which have a synergistic effect on the physiological functions and metabolic reactions of the human body, are called synbiotics.

Increased physiological effect of synbiotics is due to the fact that in the presence of prebiotics useful bacteria are developed 1,5-2 times faster. Probiotic cultures are actively developed and produce biologically active metabolites during preparation of synbiotic preparations (vitamins, enzymes).

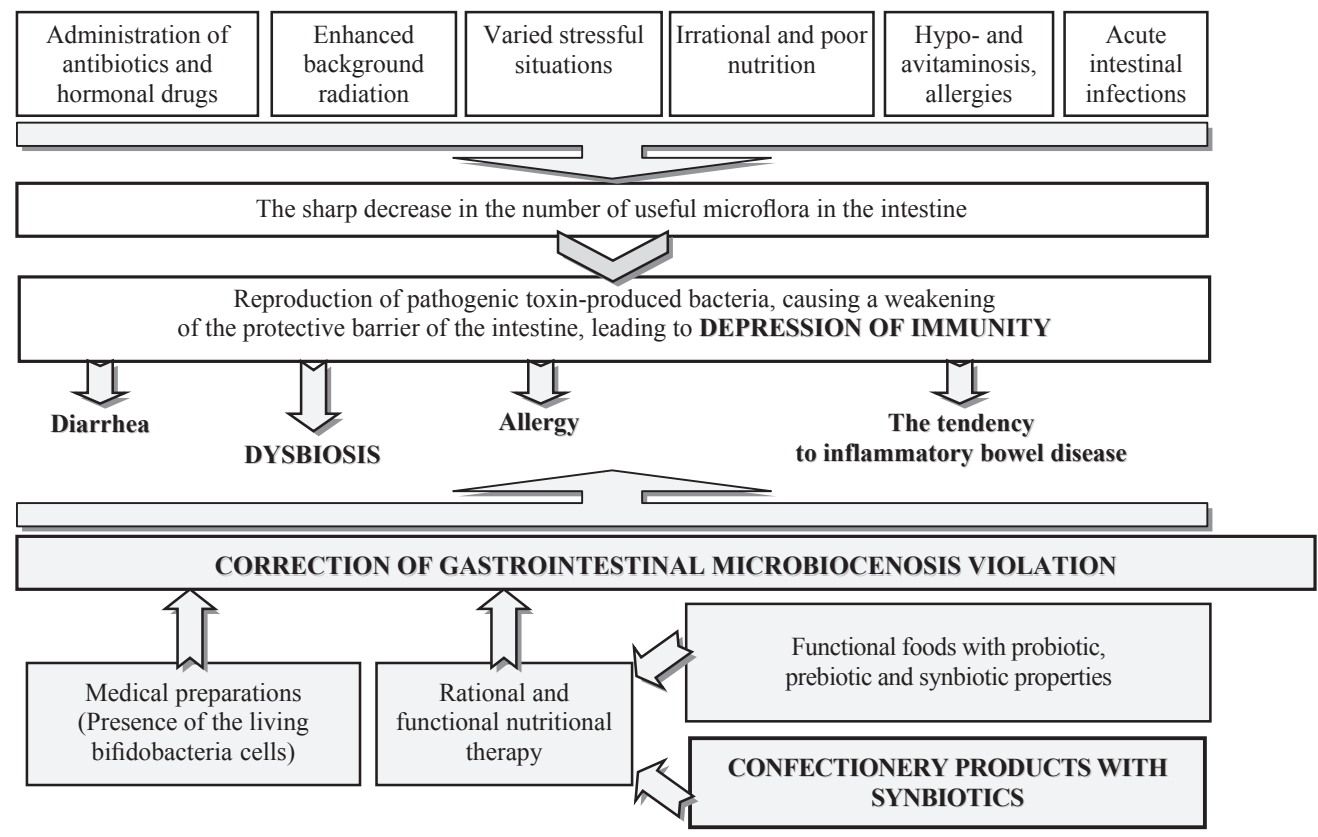

Fig. 1. Restoration of normal intestinal microflora 
After a patent search and analysis of the literature it is concluded that at present time the confectionery industry of Ukraine is not manufactured products whose composition would be included pro-, prebiotics and synbiotics as a components.

Therefore it is decided to develop a synbiotic complex and their implementation in technology of fondant candies.

\section{Methods of research}

Formulation of «Kievskaia Pomadka» fondant candies is given in this paper as a control sample, which is prepared in the traditional way [13]. Candy making technology consists of the following stages: preparation of sugar-treacle syrup, fondant syrup obtaining, fondant obtaining by cooling and churning, fondant tempering, molding, wrapping. Bifidobacteria are added in fondant tempering stage. This stage is necessary to maintain the temperature of the mass before molding by casting method between $65 \ldots 70^{\circ} \mathrm{C}$. As is known, live microorganisms in probiotic products are susceptible to the negative effect of various technological and physiological factors during production, storage and use of probiotic products (Fig. 2). In this case technological factors are high temperature of fondant, mechanical impact of stirrer of tempering machine. Physiological factors may include a low pH value (about 2-3 units) of human gastric environment during the passage of the final product, the effect of the enzyme system of the small intestine. From [14] it is known that about $90 \%$ of the probiotic cultures are died passing through the body's natural barriers.

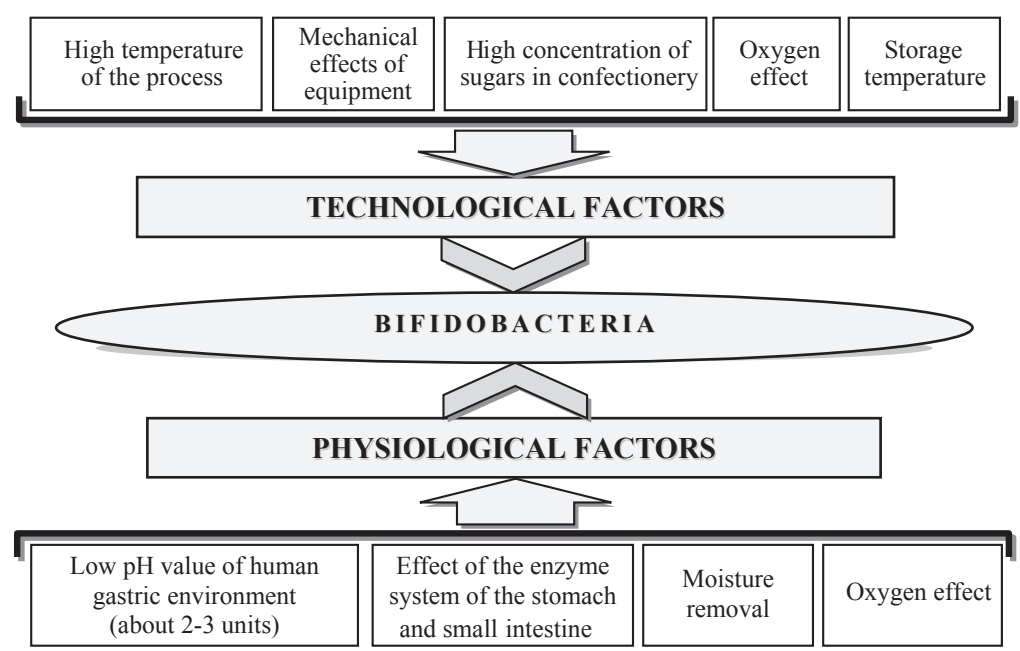

Fig. 2. Technological and physiological effects on bifidobacteria

One of the methods of improving the stability of probiotics is to use a special case of immobilization of bacterial cells - microencapsulation. The biomass of bifidobacteria is subjected to microencapsulation by special technology, which consists of the following main stages:

- Preparation of bifidobacteria.

- Preparation of a suspension of microorganisms.

- Loading in a magnetic stirrer.

- Dissolving in encapsulating material.

- Addition of metal ions $\left(\mathrm{Ca}^{2+}\right)$ in solution.

- Mixing.

- Storage.
This method is the formation of microorganisms around the shell of pectin - spherical microcapsule (size of 5-25 microns). The method is based on the application of the pectin shell on bifidobacteria and creates acidic environment resistant shell of microcapsules. It retains the biological properties of the bacteria for a long period, including during transportation to the place of their active life.

Probiotic strains of bacteria by microencapsulated form have highly antagonistic activity to various kinds of pathogens, resistance to adverse factors, resistance to digestive enzymes. It allows to adjust the release rate of the contents of capsules. Use of pectin as a shell allows to provide controlled release of the contents of capsules (bifidobacteria) in a certain part of the gastrointestinal tract, namely the colon.

Research to determine the stability of microencapsulated probiotic cultures in vitro was conducted using model digestion system [15]. It is shown that the inclusion of bifidobacteria in the gel matrix helped to preserve the number of viable cells at the negative effects of gastric juices and bile. The conducted research allowed to solve the problem of maintaining the viability of probiotic cultures and the possibility of their use in formulation of fondant candies.

Living microencapsulated microorganisms (Bifidobacteriumbifidum) were added in the experimental candy samples as a probiotics, because they are the main part of intestinal microflora; and lactulose was used as a prebiotic. The mass fraction of lactulose and a stage of its addition at the fondant preparation were determined during experiments. Lactulose were added in the first stage of the process - the preparation of sugar-treacle syrup and the mass fraction was 5; 7,5 and $10 \%$ of the solids content in the final product. A number of bifidobacteria in candy formulation was determined taking into account that the level of physiologically active microorganisms in functional foods should be $10^{6}-10^{7} \mathrm{CFU} / \mathrm{g}$.

The quality of the finished candies largely depends on the structural and mechanical properties (penetration, viscosity) of fondant.

Penetration material properties are closely associated with its structural strength, which can be evaluated quantitatively by critical shear stress $-\tau_{0}$.

\section{Research results}

The effect of synbiotic complex on fondant strength depending on the time of structure formation $B_{s}$ is analyzed. Results of effect of duration of structure formation and the mass fraction of lactulose on the strength properties of fondant are given in Table 1 .

Experimental data (Table 1) shows that candy structure strength slightly decreases with an increase in the mass fraction of lactulose. Thus, for the experimental samples of candy, containing 5; 7,5 and $10 \%$ of lactulose and microencapsulated microorganisms, critical shear stress after 10 minutes of curing is decreased by 6,18 and $30 \%$ compared to a control sample.

Strength reduction of fondant, containing a synbiotic complex, compared with the control sample, is explained by that the solids content in the fondant is presumably decreases in the test candy samples. The crystal lattice of sucrose is a structural «skeleton» of fondant. Some 
sucrose crystals due to increase of the liquid phase are changed from solid to liquid - in the inter-crystalline syrup. Thus, strength of fondant is decreased.

Tahle 1

Effect of synbiotic additive on strength properties of fondant depending on the time of structure formation

\begin{tabular}{|c|c|c|c|c|}
\hline \multirow{2}{*}{$\begin{array}{c}\text { Time of } \\
\text { structure for- } \\
\text { mation } B_{s}, \mathrm{~s}\end{array}$} & \multicolumn{4}{|c|}{$\begin{array}{c}\text { Critical shear stress } \tau_{0, \mathrm{kPa}} \text { at different mass fraction of } \\
\text { lactulose, \% and microencapsulated bifidobacteria }\end{array}$} \\
\cline { 2 - 5 } & Control & 5 & 7,5 & 10 \\
\hline 60 & 1,69 & 1,56 & 1,41 & 1,26 \\
\hline 120 & 3,12 & 2,79 & 2,52 & 2,23 \\
\hline 180 & 3,79 & 3,56 & 3,35 & 3,10 \\
\hline 300 & 15,31 & 14,9 & 13,7 & 12,9 \\
\hline 600 & 80,10 & 75,0 & 65,3 & 55,7 \\
\hline 900 & 200,8 & 175,0 & 165,2 & 150,3 \\
\hline 1200 & 310,5 & 290,7 & 280,3 & 271,5 \\
\hline
\end{tabular}

The key component for molding of fondant candies by the casting method is a mass viscosity, which is dependent on the moisture content, the proportion of the liquid phase and the temperature.

Candy fondant is structured system - the system in which there is anomaly of viscosity under deformation. Consequently, the effective viscosity of the mass depends on the velocity gradient achieved during deformation.

In the process of solidification, cooling down after cooking to $20 \ldots 10^{\circ} \mathrm{C}$ (initial temperature $70 \ldots 60^{\circ} \mathrm{C}$ ), candy fondant changes its physical state - passes from fluid-like to solid-liquid. Fondant viscosity is changed. Thus, the effective viscosity of a fondant depends on its temperature. Candy mass temperature upon molding by casting has a great importance, because when the temperature increases then its viscosity decreases and it has better cast properties. However, at elevated temperatures in the fondant after curing there is formation of large crystals whose presence is manifested as white spots. The optimum temperature for fondant casting is $65 \ldots 70{ }^{\circ} \mathrm{C}$. Researches were carried out on a rotary viscometer «Rheotest-2» of RHEOTEST Medingen GmbH (Germany) with the change in the shear rate in the range of $0,1667-72,9 \mathrm{~s}^{-1}$.

The influence of different mass fraction of lactulose and microencapsulated bifidobacteria in the viscous properties of sugar fondant were analyzed at a temperature of $70{ }^{\circ} \mathrm{C}$.

Table 2 shows the research results of the change in the effective viscosity of fondant on the gradient of shear rate with different contents of lactulose additive and encapsulated microorganisms.

Obtained data shows that effective viscosity at a shear rate of $0,1667 \mathrm{~s}^{-1}$ in the control sample was $19,6 \mathrm{kPa} \cdot \mathrm{s}$, and in the samples containing probiotic microorganisms and lactulose of $5 ; 7,5$ and $10 \%$, respectively - 14,49; 14,32 and $13,33 \mathrm{kPa} \cdot \mathrm{s}$ in the case of addition of additives into the fondant. Viscosity reduction of fondant is likely to occur due to the fact that the microorganisms are added in fondant in a liquid form with high humidity, which reduces the solids content in fondant.

In accordance with the objectives of research it was of interest to evaluate the effect of shear rate gradient, as well as the mass fraction of lactulose and microencapsulated bacteria on the fondant viscosity. Fig. 3 shows the relationship of fondant viscosity, shear rate gradient and synbiotic supplement. This dependence allows to simulate the rheological behavior of fondant on the value of $D_{r}$ and the mass fraction of additive.

Table 2

The dependence of the effective viscosity ( $\eta$ ) of fondant from shear rate gradient $\mathrm{Dr}$ with different content of lactulose and microencapsulated bifidobacteria

\begin{tabular}{|c|c|c|c|c|}
\hline \multirow{2}{*}{$\begin{array}{c}\text { Shear rate } \\
\text { gradient } \\
D_{r^{\prime}} \mathrm{s}^{-1}\end{array}$} & \multicolumn{4}{|c|}{$\begin{array}{c}\text { Effective viscosity } \eta(\mathrm{kPa} \cdot \mathrm{s}) \text { at different mass fraction } \\
\text { of lactulose, \% and microncapsulated bifidabacteria }\end{array}$} \\
\cline { 2 - 5 } & Control & 5 & 7,5 & 10 \\
\hline 0,1667 & 19,6 & 14,49 & 14,32 & 13,33 \\
\hline 0,3 & 11,2 & 10,94 & 8,65 & 8,65 \\
\hline 0,5 & 7 & 6,7 & 6,45 & 5,84 \\
\hline 0,9 & 4,2 & 3,9 & 3,64 & 3,6 \\
\hline 1,5 & 3,08 & 2,4 & 2,24 & 2,2 \\
\hline 2,7 & 1,6 & 1,4 & 1,3 & 1,27 \\
\hline 4,5 & 0,9 & 0,89 & 0,8 & 0,78 \\
\hline 8,1 & 0,49 & 0,52 & 0,46 & 0,44 \\
\hline 13,5 & 0,28 & 0,33 & 0,28 & 0,27 \\
\hline 24,3 & - & 0,19 & 0,16 & 0,15 \\
\hline 40,5 & - & 0,11 & 0,1 & 0,09 \\
\hline 72,9 & - & 0,068 & 0,063 & 0,055 \\
\hline
\end{tabular}

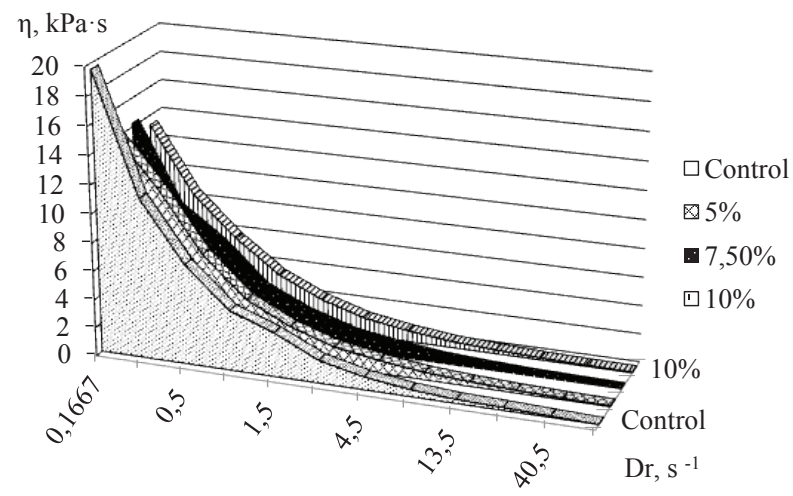

Fig. 3. Dependence of the effective viscosity of fondant on the shear rat gradient and synbiotic additive

The main indicators that characterize the chemical properties of fondant candies are titrated acidity, dry matter content and the content of reducing substances, the results of which are shown in Table 3 .

Table 3

Quality indicators of fondant candies with synbiotic complex

\begin{tabular}{|c|c|c|c|}
\hline \multirow{2}{*}{$\begin{array}{l}\text { Mass fraction } \\
\text { of additive, \% }\end{array}$} & \multicolumn{3}{|c|}{$\begin{array}{l}\text { Quality indicators of fondant candies with } \\
\text { synbiotic complex }\end{array}$} \\
\hline & $\begin{array}{l}\text { Solids content - } \\
\qquad, \%\end{array}$ & $\begin{array}{l}\text { Titrated acidity - } \\
T \text {, degree }\end{array}$ & $\begin{array}{c}\text { Reducing } \\
\text { substances } \\
\text { content - RS, \% }\end{array}$ \\
\hline Control & 90 & 1,0 & 9,2 \\
\hline 5 & 88 & 1,8 & 13,2 \\
\hline 7,5 & 88 & 2,0 & 15,3 \\
\hline 10 & 88 & 2,3 & 19,2 \\
\hline
\end{tabular}


Thus, acidity in a control sample is 1 degree, and in the test candies with mass lactulose fraction of $5 ; 7,5$ and $10 \%-1,8 ; 2,0$ and 2,3, respectively. Acidity increase with increase of mass fraction of lactulose can be explained by the fact that titrated acidity of additive is higher than sugar.

Reduction of the solids content in the test candies is caused by addition of microencapsulated bifidobacteria solution with high humidity ( $W=89 \%$ ) into the formulation.

Increase of reducing substances content in the test candies in comparison with control is caused by replacing of non-reducing sugars (sucrose) on reducing -lactulose. Moreover, the content of reducing substances in samples of fondant candies containing 7,5 and $10 \%$ of lactulose is higher than reducing substances index, which is regulated by the DSTU 4135:2002. Therefore, the mass fraction of lactulose, which can be added into the fondant candies, should not exceed $5 \%$.

An important indicator of the product's functionality is the number of viable bifidobacteria cells in fondant candies at the end of their shelf life. Obtained data are presented in Fig. 4.

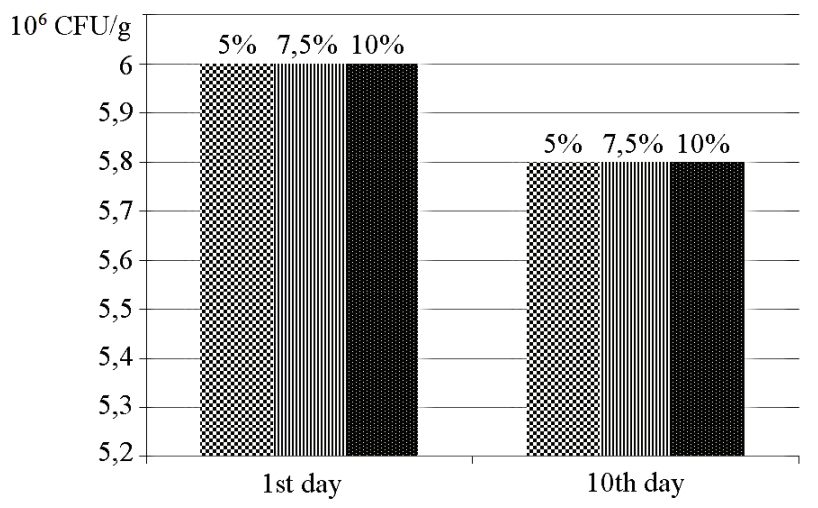

Fig. 4. Change of the number of viable cells B. bifidum during storage of fondant candies with a mass lactulose fraction of 5; 7,5 and $10 \%$

Control sample, in which unprotected bifidobacteria cells are added, are also analyzed in the experiments. There are no microbial cells in it after 10 days (according to DSTU 4135:2002).

The content of bifidobacteria in fondant candies at the time of preparation is in average $6 \times 10^{6} \mathrm{CFU} / \mathrm{g}$. After storing this indicator is slightly reduced and is $5,8 \times 10^{6} \mathrm{CFU} / \mathrm{g}$. That is, the experimental data support the use of bifidobacteria microencapsulation to maintain their viability.

As a research results, the project of normative documents for experimental lot of fondant candies with synbiotic complex (specifications, technological instructions, formulation) was developed and a patent for utility model of Ukraine was received [16].

\section{SWOT analysis of research results}

Strengths. The strengths of this research are necessary to allocate the results to identify bifidobacteria microencapsulation technology. It allows to achieve almost $100 \%$ delivery of beneficial bacteria in the intestines. Also, the use of microencapsulation helps to preserve the survival of beneficial bacteria in fondant candies throughout the storage period.
Microencapsulation opens interesting prospects for a wide addition of probiotic substances into confectionery formulations, their survival in the conditions of the process, regulating the release rate of microorganisms in certain sections of the gastrointestinal tract.

Developed fondant candies with synbiotics allow to provide the human body is not so much the energy and plastic material as to control and simulate specific physiological functions. These features are aimed at the normalization of intestinal microflora and enhance human immunity.

Also, the use of synbiotics in fondant candies technology will receive and process effects: to improve the structural and mechanical properties of fondant, slow down the «staling» process by reducing moisture loss and prevention of sucrose crystallization.

Weaknesses. A weakness of this development can be considered the cost of finished products, which will increase due to the use microencapsulated bifidobacteria in the formulation of candies. Also, the introduction of this technology requires additional costs. They are connected with the creation and development of technical (instrumental) basis for new products, which will lead to a slight decrease in profitability of the enterprise at an initial stage.

Opportunities. Additional features of the proposed technological solutions lie in an attempt of manufacturers to expand the range of confectionery and finding ways to manufacture available products of functional orientation.

Threats. Threats to introduce of obtained types of products in the production are related to two main factors. Firstly, the economic difficulties and uncertainty in the future work of the confectionery factories in today's challenging environment. At the same time the desire of manufacturer to introduce and production of products of a functional purpose isn't enough. This requires additional investment and attraction of highly qualified professionals. Secondly, enterprise must conduct market studies on consumer demand for this type of product.

Thus, SWOT analysis of research results allows to determine the main directions for the successful solution of the research objectives. Among them: analysis of the major trends in creating functional confectionery, theoretical and practical approach to development of formulations with functional ingredients, calculation of the cost-effectiveness of the proposed technological solutions.

\section{Conclusions}

1. The method of bifidobacteria microencapsulation for their «protection» from the effects of negative factors is developed. Solid shell of microcapsules eliminates destructive contact of microorganisms with an aggressive (acidic) environment of the stomach and alkaline - duodenum. Bifidobacteria are also protected from the effects of heat and mechanical action of stirrer of tempering machine during production of fondant candies.

2. Synbiotic complex consisting of microencapsulated bifidobacteria and lactulose is developed and proved. This symbiotic has a beneficial effect on the health of the host organism, improving survival and engraftment of live bacterial additives in the intestine and selectively stimulating the growth and activation of the metabolism of bifidobacteria. This will create a new kind of functional 
fondant candies that can restore the normal microflora of the body and at the same time preventing dysbiosis disease.

Experimental data on the effect of synbiotic complex on physical-chemical and structural-mechanical properties of fondant, which suggests that the addition of a synbiotic additive helps to reduce the fondant viscosity, which plays a positive role in the fondant molding by casting method. The relationship of viscosity of fondant, shear rate gradient and synbiotic supplement is determined. It is allows to simulate the rheological behavior of fondant on the value of $\mathrm{Dr}$ and the mass fraction of additives. The optimal mass fraction of lactulose is in an amount of $5 \%$, which can be added into the formulation of fondant candies.

Thus, the inclusion of fondant candies with synbiotic complex in the diet will increase the biosafety of products, strengthen the immune system and reduce the risk of gastrointestinal diseases. With confidence we can say that the production of functional confectionery products, using innovative technologies, becomes a strategic direction in the development of food production that ensures the creation of health, therapeutic and prophylactic products.

\section{References}

1. Analiz ukrainskogo rynka konfet [Electronic resource] // KOLORO Brend Design. - 28.03.2016. - Available at: \www/ URL: http://koloro.ua/blog/issledovaniya/Analiz-ukrainskogorynka-konfet.html

2. Shafranskii, V. V. Shchorichna dopovid pro stan zdorovia naselennia, sanitarno-epidemichnu sytuatsiiu ta rezultaty diialnosti systemy okhorony zdorovia Ukrainy. 2015 rik [Text] / by ed. V. V. Shafranskii; Ministry of Health of Ukraine, SI «Ukrainian Institute of Strategic Research of Ministry of Health of Ukraine». - Kyiv, 2016. - 452 p.

3. Cheikhyoussef, A. Antimicrobial proteinaceous compounds obtained from bifidobacteria: From production to their application [Text] / A. Cheikhyoussef, N. Pogori, W. Chen, H. Zhang // International Journal of Food Microbiology. - 2008. - Vol. 125, № 3. - P. 215-222. doi:10.1016/j.ijfoodmicro.2008.03.012

4. Shenderov, B. A. Meditsinskaia mikrobnaia ekologiia i funktsional'noe pitanie [Text]. Vol. 3. Probiotiki i funktsional'noe pitanie / B. A. Shenderov. - Moscow: Grant, 2001. - 288 p.

5. Biavati, B. The Family Bifidobacteriaceae [Text] / B. Biavati, P. Mattarelli // The Prokaryotes. - Springer Nature, 2006. P. 322-382. doi:10.1007/0-387-30743-5_17

6. Piksasova, O. V. Methods of Molecular Identification as Important Tools for Control and Certification in Microbioligy [Text] / O. V. Piksasova, M. A. Kornienko, Yu. D. Tsygankov, A. I. Netrusov // Electronic Journal of Natural Sciences. - 2009. Vol. 1. - P. 35-49.

7. Feklisova, L. V. Novyi mikrobnyi preparat «Bifitsid» pri lechenii detei s ostrymi kishechnymi zabolevaniiami [Text] / L. V. Feklisova, V. I. Ganina, V. F. Inozemtseva, L. V. Titova, O. Yu. Leonteva // Rossiiskii vestnik perenatologii i pediatrii. - 1995. - № 7 . P. 21-26.
8. Kapreliants, L. V. Prebiotiki: himiia, tehnologiia, primenenie [Text] / L. V. Kapreliants. - Kyiv: EnterPrint, 2015. - 252 p.

9. Monsan, P. Enzymatic synthesis of oligosaccharides [Text] / P. Monsan, F. Paul // FEMS Microbiology Reviews. - 1995. - Vol. 16, № 2-3. - P. 187-192. doi:10.1111/j.1574-6976.1995.tb00165.x

10. Riabtseva, S. A. Tehnologiia laktulozy [Text]: Textbook / S. A. Riabtseva. - Moscow: DeLiprint, 2003. - 232 p.

11. Igarashi, C. Effects of whey calcium and lactulose on the strength of bone in ovariectomized osteoporosis model rats [Text] / C. Igarashi, I. Ezawa // Pharmacometrics. - 1991. - Vol. 42. P. 245-253.

12. Voragen, A. G. J. Technological aspects of functional foodrelated carbohydrates [Text] / A. G. J. Voragen // Trends in Food Science \& Technology. - 1998. - Vol. 9, № 8-9. P. 328-335. doi:10.1016/s0924-2244(98)00059-4

13. Zubchenko, A. V. Tehnologiia konditerskogo proizvodstva [Text]: Textbook / A. V. Zubchenko. - Voronezh: VSTA,1999. - 432 p.

14. Anan'eva, N. V. Application of the immobilized forms of probiotic bacteria in milk products manufacturing [Text] / N. V. Anan'eva, V. I. Ganina, N. V. Nefedova, G. R. Gabril'yan // Molochnaya promyshlennost. - 2006. - № 11. - P. 46-47.

15. Korkach, H. V. Rozrobka tekhnolohii pomadnykh tsukerok funktsionalnoho pryznachennia [Text] / H. V. Korkach, V. H. Muratov, I. O. Kyrtoka // Materialy IV Vseukrainskoi naukovopraktychnoi konferentsii «Novitni tendentsii u kharchovykh tekhnolohiiakh ta yakist i bezpechnist produktiv». - Lviv, 2012. - P. 48-51.

16. Method for making fondant sweets [Electronic resource]: $\mathrm{Pa}$ tent UA 77558 U, MPK A 23 G 3/00 / Korkach H. V., Kyrtoka I. O.; assignee: Odessa National Academy of Food Technologies. - № u201206905; filed 05.06.2012; published 25.02.2013, Bull. № 4. - Available at: \www/URL: http://uapatents.com/ 4-77558-sposib-virobnictva-pomadnikh-cukerok.html

\section{РАЗРАБОТКА ИННОВАЦИОННЫХ ТЕХНОЛОГИЙ ЛОМАДНЫХ КОНФЕТ С СИНБИОТИКАМИ}

Изучена роль процесса микрокапсулирования микроорганизмов с целью их защиты от неблагоприятных факторов. Доказана целесообразность создания синбиотичного комплекса и изучено влияние его на физико-химические и структурномеханические свойства помадных масс. Приведены результаты по разработке технологии помадных конфет с синбиотическим комплексом, в котором в качестве пробиотических культур использовались микрокапсулированные бифидобактерии, а в качестве пребиотика - лактулоза.

Ключевые слова: микрокапсулированные бифидобактерии, пребиотик лактулоза, синбиотики, микрокапсулирование, помадные конфеты.

Korkach Hanna, PhD, Associate Professor, Department of Technology of Bread, Pastry, Pasta and Food Concentrates, Odessa National Academy of Food Technologies, Ukraine, e-mail: kor2007@ukr.net, ORCID: http://orcid.org/0000-0002-9147-5508

Krusir Galina, Doctor of Technical Sciences, Professor, Head of Department of Ecology and Nature Protection Technologies, Odessa National Academy of Food Technologies, Ukraine, e-mail: krusir_65@mail.ru, ORCID: http://orcid.org/0000-0002-2451-2364 